
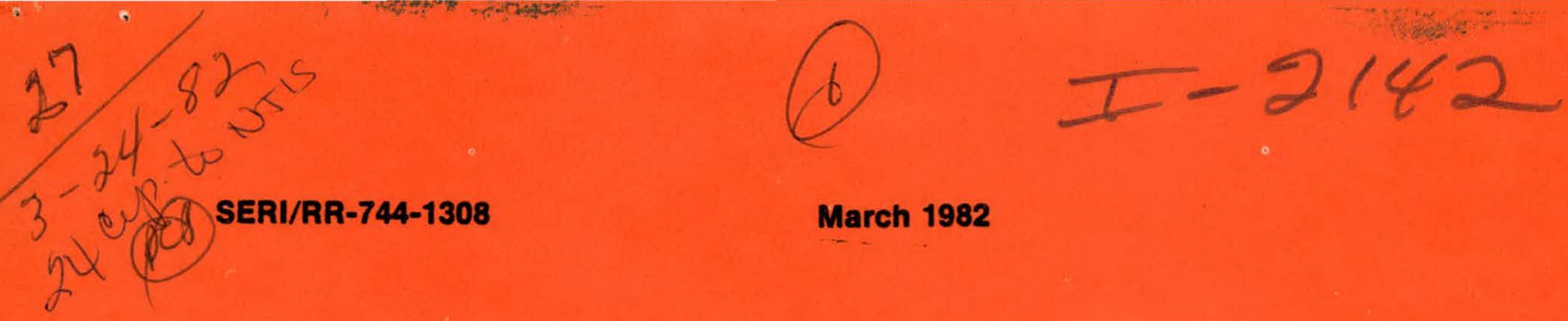

March 1982

\title{
Energy Conservation in Rental Housing: \\ Landlords' Perceptions of Problems and Solutions
}

\author{
Alice Levine \\ Jonathan Raab \\ Bruce Astrein \\ Scott Bernstein \\ Craig Plernot \\ Steven Strahs
}


Solar Energy Research Institute

A Division of Midwest Research Institute

1617 Cole Boulevard

Golden, Colorado 80401

Operated for the

U.S. Department of Energy under Contract No. EG-77-C-01-4042 


\section{DISCLAIMER}

This report was prepared as an account of work sponsored by an agency of the United States Government. Neither the United States Government nor any agency Thereof, nor any of their employees, makes any warranty, express or implied, or assumes any legal liability or responsibility for the accuracy, completeness, or usefulness of any information, apparatus, product, or process disclosed, or represents that its use would not infringe privately owned rights. Reference herein to any specific commercial product, process, or service by trade name, trademark, manufacturer, or otherwise does not necessarily constitute or imply its endorsement, recommendation, or favoring by the United States Government or any agency thereof. The views and opinions of authors expressed herein do not necessarily state or reflect those of the United States Government or any agency thereof. 


\section{DISCLAIMER}

Portions of this document may be illegible in electronic image products. Images are produced from the best available original document. 


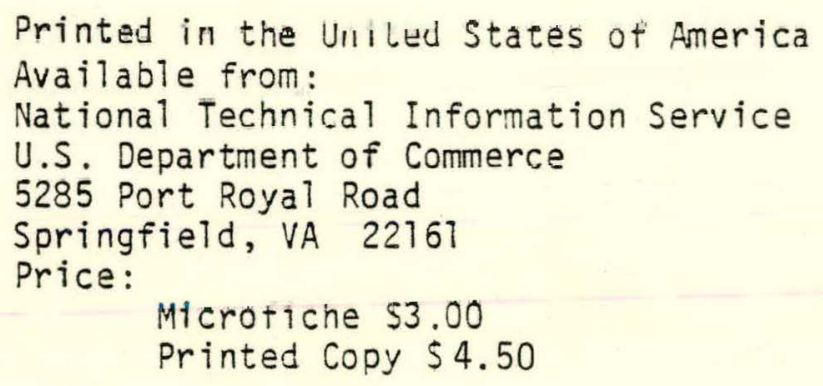

\section{NOTICE}

This report was prepared as an account of work sponsored by the United States Government. Neither the United States nor the United States Department of Energy, nor any of their employees, nor any of their contractors, subcontractors, or their employees, makes any warranty, express or implied, or assumes any legal liability or responsibility for the accuracy, completeness or usefulness of any information, apparatus, product or process disclosed, or represents that its use would not infringe privately owned rights. 
SERI/AR-744-1308

UC Category: 58

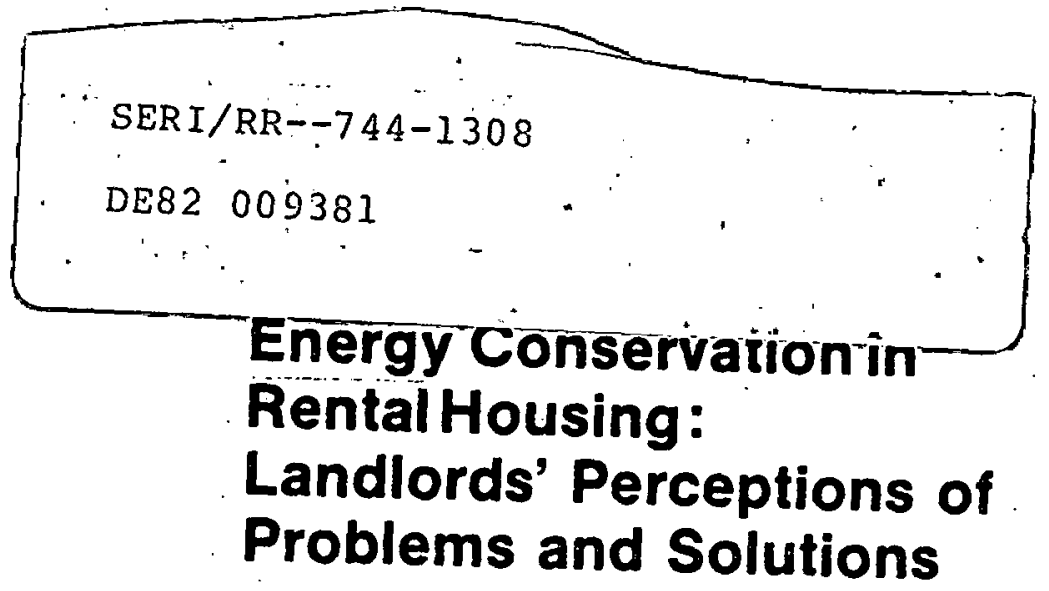

\begin{abstract}
Alice Levine Jonathan Raab

Bruce Astrein

Scott Bernstein

Craig Piernot

Steven Strahs
\end{abstract}

March 1982 .

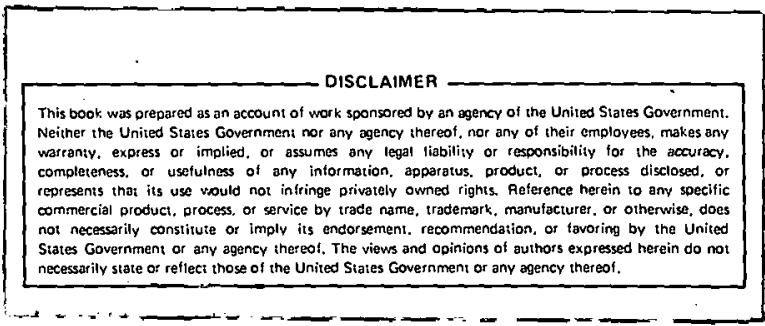

Prepared Under Task No. 1195.00

WPA No. 005A-81

Solar Energy Research Institute

A Division of Midwest Research Institute

1617 Cole Boulevard

Golden, Colorado 80401

Prepared for the

U.S. Department of Energy

Contract No. EG-77-C-01-4042






\section{PAGES ii to iv WERE INTENTIONALLY LEFT BLANK}


TABLE OF CONTENTS

$\underline{\text { Page }}$

1.0 Introduction $\ldots \ldots \ldots \ldots \ldots \ldots \ldots \ldots \ldots \ldots \ldots \ldots \ldots \ldots \ldots \ldots \ldots \ldots \ldots \ldots$

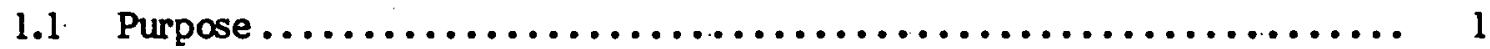

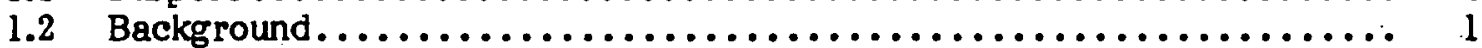

1.3 Summary of Major Findings.$\ldots \ldots \ldots \ldots \ldots \ldots \ldots \ldots \ldots \ldots \ldots \ldots \ldots \ldots \ldots$

2.0 Method $\ldots \ldots \ldots \ldots \ldots \ldots \ldots \ldots \ldots \ldots \ldots \ldots \ldots \ldots \ldots \ldots \ldots \ldots \ldots \ldots \ldots \ldots \ldots \ldots, 5$

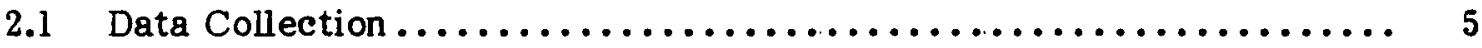

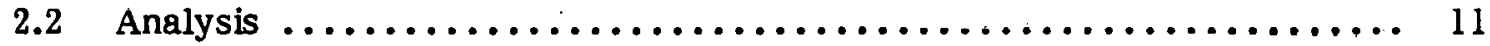

3.0 Conservation Measures.................................. 13

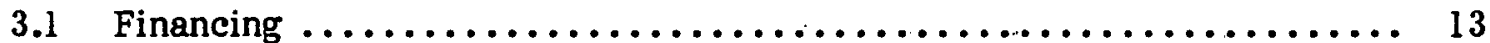

3.2 Landlords' Reasons for Energy Conservation Investments $\ldots \ldots \ldots \ldots \ldots \ldots 14$

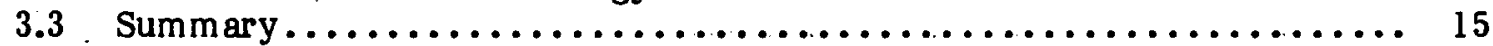

4.0 Laridlords' Perceptions of Barriers to Conservation Investments ............ 17

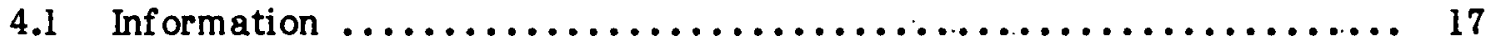

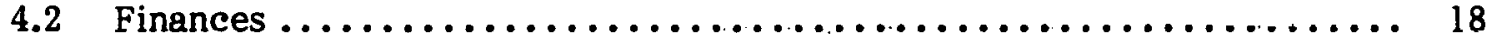

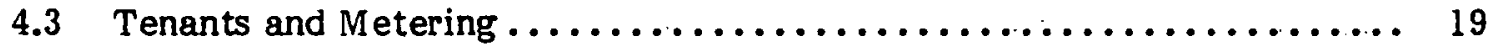

4.4 Technology ....................................... 19

4.5 Regulations $\ldots \ldots \ldots \ldots \ldots \ldots \ldots \ldots \ldots \ldots \ldots \ldots \ldots \ldots \ldots \ldots \ldots \ldots \ldots \ldots$

5.0 Landlords' Perceptions of Solutions to Energy Conservation

Problems....................................... 21

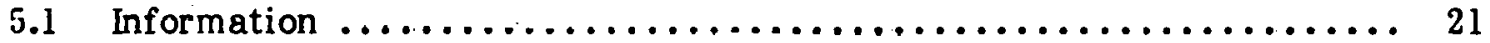

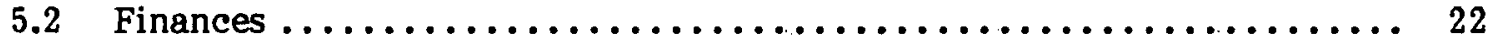



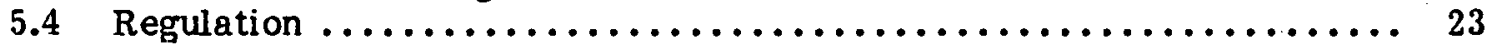



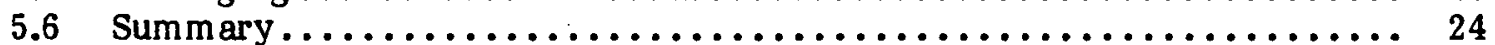

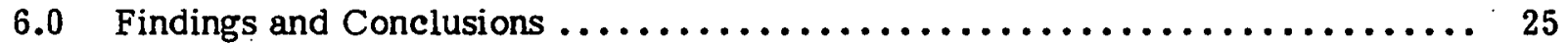

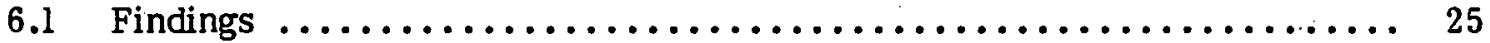

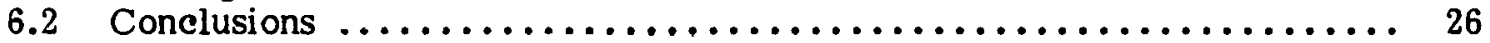

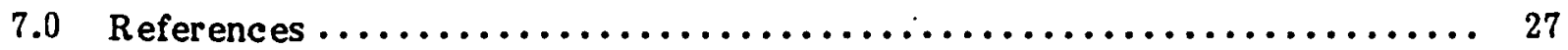

Appendix A. Overview of Cities $\ldots \ldots \ldots \ldots \ldots \ldots \ldots \ldots \ldots \ldots \ldots \ldots \ldots \ldots \ldots$

Boston .................................... 29

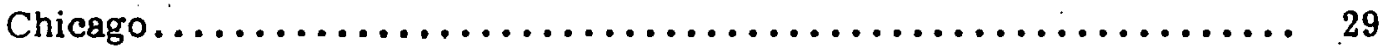

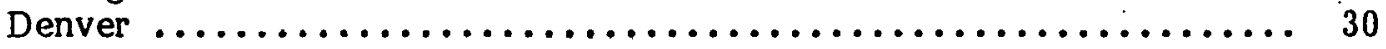




TABLE OF CONTENTS (Concluded)

Appendix B. Interview Checklists

Owner Profile

Technologies

Barriers.

Solutions 


\section{SECTION 1.0}

\section{INTRODUCTION}

Rental housing constitutes over one-third of the housing stock in the United States (GAO 1979). Although the potential energy savings in this sector are substantial (Ashworth 1980), the potential for monetary savings is not as clear. Consequently, rental housing owners have been slow to invest in energy-conserving measures, including solar energy equipment, for their rental properties. At the same time, tenants are not likely to invest much in conservation because of short tenancies, limited capital, and legal constraints, among other reasons. Federal, state, and local programs to encourage conservation in rental housing also have been noticeably absent or ineffective (Levine and Raab 1981).

Rising energy prices could increase building owners' incentives to invest in energy conservation measures. But the uncertainties accompanying projected savings, combined with declining cash flow reserves and high interest rates, seem to deter rental housing owners from making many energy conservation investments. Especially where rental housing is separately metered and tenants pay the utility bills, owners have little or no incentive to make such investments. In master-metered housing, where landlords can easily pass rising fuel costs on to tenants, they do so. Rental housing remains largely energy inefficient, therefore, and there continues to be a lack of incentives for landlord investment in energy conservation measures.

\subsection{PURPOSE}

This report describes rental housing owners' concerns and decisions about energy conservation investments for their properties. It contributes to the design of the U.S. Department of Energy's (DOE) Innovative Delivery Demonstration Program. The research effort outlines in a preliminary fashion important barriers to conservation and solutions to the problem as they are perceived by landlords.

\subsection{BACKGROUND}

This research builds on a preliminary investigation into the problems facing landlords and tenants as energy costs escalate (Levine and Raab 1981). That investigation showed that programs and policies at federal, state, and local levels will be most effective when targeted specifically to rental housing rather than to the entire residential sector; and when they are targeted to owners rather than to tenants within the rental sector itself. General real estate investment criteria were described, and results were extrapolated based on knowledge of the real estate market and on the experience of state and local program administrators.

Rental housing owners varied in their propensity to invest in energy conservation measures according to how their buildings are metered, how much property they hold, how long they intend to hold the property, whether their units are subsidized, and an array of other locally sensitive factors; including local energy costs and the presence or absence of incentives.

Thirty-five in-depth, unstructured interviews with landlords in this research further explored landlords' perceptions of their own energy problems. This work contributes to 
the design of DOE's Innovative Delivery Demonstration Program by documenting specific decision processes and investment criteria with a carefully selected, purposive sample of landlords, using their actual energy and conservation investments as a point of departure.

\subsection{SUMMARY OF MAJOR FINDINGS}

The findings of this research represent landlords' perceptions of the most significant existing barriers to energy conservation and some ways they proposed to overcome those barriers. When landlords were motivated to carry out energy conservation measures, they did so to save money, not energy.

In general, the barriers to energy conservation that these landlords perceived fell into five major categories:

- Information

- Finances

- Tenants and metering

- Technology

- Regulations.

Within these categories were more specific barriers (detailed in Sec. 4.0), described according to which types of landlords found each obstacle to be most important.

Landlords' perceived solutions to energy conservation problems almost mirrored the barriers. The five categories included the following:

- Information

- Finances

- Tenants and metering

- Regulations

- Packayilig.

Although many landlords noted technological barriers, they offered few solutions to technology-related problems. We had a special research interest in the aoceptability of a packaged approach to energy conservation, where information, installation, and financing are provided by one company, and many landlords were responsive to that approach. Specific solutions within each category are described in Sec. 5.0, again according to which types of landlords pref erred them.

On specific barriers to energy conservation and proposed measures to overcome them, rental housing owners' op tions seemed to vary most according to how their buildings were metered, how many units were owned, and the intended length of ownership. Other factors also influenced rental housing owners' energy investment decisions, including whether the building was subsidized; whether rents were controllcd; and whether local financing, state tax credits, and utility programs were available. In addition, landlords who were owner/occupants were, predictably, more likely to invest in energy conservation measures. 
Although the perceptions of rental housing owners themselves can help describe areas in need of particular attention by the private market or public policy designers, it is important to remember that the solutions noted here are proposed by landlords in the pursuit of profit. Little attention is given to questions of the equitable distribution of the costs and benefits of energy conservation among tenants and landlords. Nor do we attempt to make policy recommendations based on the interviews. 


\section{S퀴}

1 


\section{SECTION 2.0}

\section{METHOD}

The research was designed to elicit specific responses from rental housing owners about their energy-related concerns in operating rental housing. The study was a preliminary one aimed at outlining general areas of concern to rental housing owners regarding energy use in their buildings. We interviewed 35 rental housing owners or managers (the person who makes the final energy conservation investment decision). The interviews were conducted using agreed-upon lists of issues to guide open-ended discussion. Interviews were conducted in four cities: Boston, Chicago, Denver, and San Francisco (see Table 2-1). The cities were chosen to represent variations in the predominant fuel types, housing stock, density, climate, general economic conditions, presence or absence of state and local incentives, and presence or absence of rent control.

In each city, rental housing owners or managers were carefully selected to represent variations in size of building owned, how buildings are metered, geographic location within the city, and form of ownership. At least one rental housing owner of federally subsidized units was interviewed in each city (see Tables 2-2 and 2-3).

\subsection{DATA COLLECTION}

The interviewers and the project director agreed on a consistent format for the openended discussions with landlords. Some variation in interviewer style and bias was inevitable, but differences were kept to a minimum by using interview checklists that embodied a common understanding of the issues and problems, and clear, common definitions of rental housing market terminology. One pretest interview was conducted in each city, and the checklists were redrafted in accordance with pretest results (see Appendix B). The first checklist established an owner profile. Interviewers asked questions about the buildings, the owners' involvement in real estate, and the owners' operating procedures.

The second checklist was used to determine what energy conservation improvements owners had made already. The interviewer selected one improvement (by highest cost or complexity of the measure) and asked the owner about the process for making that particular improvement.

With the third checklist, owners were asked to identify reasons for not making further energy-related improvements. Each owner was shown a list of 11 categories of barriers and was asked to describe experience with each barrier including each one's relative importance to his or her decisions relating to energy conservation improvements. The fourth and final checklist gave owners the opportunity to express their preferred solutions. After asking an open-ended question about solutions to their energy problems, interviewers prompted owners with a list of 10 general program areas.

We were particularly interested in owners' reactions to a packaged approach to energy management in their buildings: information about appropriate techniques for energy conservation in particular buildings; a financial analysis of those investments; installation of selected energy conservation measures; and in the cases of high-cost measures, financing the investment over time. 
Table 2-1. SUMMARY OF RENTAL HOUSING OWNERS INTER VIEWED

\begin{tabular}{|c|c|c|c|c|c|}
\hline Owner & $\begin{array}{l}\text { No. of Buildings/ } /^{a, b} \\
\text { No. of Units }\end{array}$ & Jwnership & Metering ${ }^{c}$ & Subsidized & City \\
\hline 1 & $1 / 3$ & $\begin{array}{l}\text { Single proprietor } \\
\text { Owner-occupied }\end{array}$ & Separate & No & Boston \\
\hline 2 & $1 / 3$ & Single proprietor & $\begin{array}{l}\text { Master- } \\
\text { space and hot water } \\
\text { Separate- } \\
\text { electricity }\end{array}$ & No & Chicago \\
\hline 3 & $3 / 3$ & Single proprietor & Separate & No & Denver \\
\hline 4 & $1 / 4$ & $\begin{array}{l}\text { Single proprietor } \\
\text { Owner-oceupied }\end{array}$ & $\begin{array}{l}\text { Separate- } \\
\text { space and electricity } \\
\text { Master- } \\
\text { hot water }\end{array}$ & No & San Francisco \\
\hline 5 & $1 / 6$ & Singte proprietor & $\begin{array}{l}\text { Separate- } \\
\text { space and electricity } \\
\text { Master- } \\
\text { hot water }\end{array}$ & No & Chicago \\
\hline 6 & $3 / 8.5$ & Sing e proprietor & Separate & No & Boston \\
\hline 7 & $1 / 12$ & Partiership & $\begin{array}{l}\text { Master- } \\
\text { space and hot water } \\
\text { Separate- } \\
\text { electricity }\end{array}$ & No & San Francisco \\
\hline 8 & $2 / 14$ & $\begin{array}{l}\text { Partnership-12 units } \\
\text { Proprietor-2 units }\end{array}$ & $\begin{array}{l}\text { Separate- } \\
\text { space and electricity } \\
\text { Master- } \\
\text { hot water }\end{array}$ & No & San Francisco \\
\hline
\end{tabular}

a Holdings in city limits only.

b Several owners included units that they manage but do not own.

c Metering is described for the inits only, not for common space. 
Table 2-1. SUMMARY OF RENTAL HOUSING OWNERS INTERVIEWED (continued)

\begin{tabular}{|c|c|c|c|c|c|}
\hline Owner & $\begin{array}{l}\text { No. of Buildings/ } \\
\text { No. of Units }\end{array}$ & Ownership & Metering & Subsidized & City \\
\hline 9 & $1 / 15$ & Single proprietor & $\begin{array}{l}\text { Master- } \\
\text { space and hot water } \\
\text { Separate- } \\
\text { electricity }\end{array}$ & $\begin{array}{l}\text { Yes, } \\
7 \text { units }\end{array}$ & Chicago \\
\hline 10 & $1 / 23$ & Single proprietor & $\begin{array}{l}\text { Separate- } \\
\text { space and electricity } \\
\text { Master- } \\
\text { hot water and common } \\
\text { space lighting }\end{array}$ & No & San Francisco \\
\hline 11 & $1 / 24$ & Partnership & $\begin{array}{l}\text { Master- } \\
\text { space and hot water } \\
\text { Separate- } \\
\text { electricity }\end{array}$ & No & San Francisco \\
\hline 12 & $4 / 25$ & Single proprietor & $\begin{array}{l}\text { Master- } \\
\text { space } \\
\text { Separate- } \\
\text { hot water and electricity }\end{array}$ & $\begin{array}{l}\text { No } \\
\cdots \\
\ddots\end{array}$ & Boston \\
\hline 13 & 22,32 & Single proprietor & Separate & No & Denver \\
\hline 14 & $1 / 36$ & Partnership & $\begin{array}{l}\text { Master- } \\
\text { space and hot water } \\
\text { Separate- } \\
\text { electricity }\end{array}$ & No & San Francisco \\
\hline 15 & $3 / 36$ & Land trust & Separate & No & Chicago \\
\hline 16 & $2 / 37$ & Partnership & $\begin{array}{l}\text { Master-space, one } \\
\text { building } \\
\text { Separate- } \\
\text { all others }\end{array}$ & No & Chicago \\
\hline 17 & $3 ; 95$ & $\begin{array}{l}\text { Nonprofit } \\
\text { development } \\
\text { corporation }\end{array}$ & Mixed & $\begin{array}{c}\text { Yes, } \\
18 \text { units }\end{array}$ & San Francisco \\
\hline
\end{tabular}


Table 2-1. SUMMARY OP RENTAL HOUSING OWNERS INTER VIEWED (continued)

\begin{tabular}{|c|c|c|c|c|c|}
\hline Owner. & $\begin{array}{l}\text { No. of Builc̈ings/ } \\
\text { No. of Uritts }\end{array}$ & Ownership & Metering & Subsidized & City \\
\hline 18 & $\begin{array}{l}\text { Many single and } \\
\text { multif amily/ } \\
\text { many units }\end{array}$ & $\begin{array}{l}\text { Real estate } \\
\text { corporatiori }\end{array}$ & Mixed & No & San Francisco \\
\hline 19 & $\begin{array}{l}\text { Many multi- } \\
\text { family/many } \\
\text { units }\end{array}$ & $\begin{array}{l}\text { Maragement firm/ } \\
\text { parinership/ } \\
\text { Single proprietor }\end{array}$ & Mixed & No & San Francisco \\
\hline 20 & $5 / 200$ & Parinership & $\begin{array}{l}\text { Master- } \\
\text { space } \\
\text { Separate- } \\
\text { hot water, electricity }\end{array}$ & $\begin{array}{c}\text { Yes, } \\
20 \text { units }\end{array}$ & Chicago \\
\hline 21 & $15 / 210$ & Partnership & Separate & No & Denver \\
\hline 22 & $43 / 36 i$ & Partnership & $\begin{array}{l}\text { Master- } \\
60 \% \text { space and hot water } \\
\text { Separate- } \\
\text { remainder }\end{array}$ & Yes & Denver \\
\hline 23 & $7 / 500$ & Partnership & $\begin{array}{l}\text { Master- } \\
\text { space } \\
\text { Separate- } \\
\text { hot water; electricity }\end{array}$ & Yes & Boston \\
\hline 24 & $15^{d / 500}$ & Partiership & $\begin{array}{l}\text { Master- } \\
\text { space } \\
\text { Separate- } \\
\text { hot water, electricity }\end{array}$ & $\begin{array}{c}\text { Yes, } \\
150 \text { units }\end{array}$ & Chicago \\
\hline 25 & $27 / 600$ & $\begin{array}{l}\text { Partnership } \\
-26 \text { buildings } \\
\text { Single proprietor } \\
\text {-1 building }\end{array}$ & $\begin{array}{l}\text { Separate } \\
\text { (in process of } \\
\text { converting) }\end{array}$ & Yes & Chicago \\
\hline 26 & $4 / 600$ & Partriership & Master & Yes & Boston \\
\hline
\end{tabular}

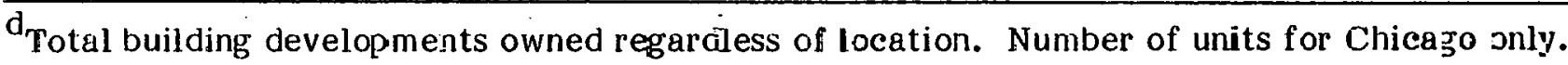


Table 2-1. SUMMARY OF RENTAL HOUSING OWNERS INTERVIEWED (concluded)

\begin{tabular}{|c|c|c|c|c|c|}
\hline Owner & $\begin{array}{l}\text { No. of Buildings/ } \\
\text { No. of Units }\end{array}$ & Ownership & Metering & Subsidized & City \\
\hline 27 & $25 / 600$ & Realty trust & $\begin{array}{l}\text { Master- } \\
\text { space } \\
\text { Separate } \\
\text { hot water, electricity }\end{array}$ & No & Boston \\
\hline 28 & $\begin{array}{r}50 / 600 \\
.\end{array}$ & Corporation & $\begin{array}{l}\text { Master- } \\
\text { space } \\
\text { Separate- } \\
\text { hot water, electricity }\end{array}$ & No & Boston \\
\hline 29 & $32 / 1,000$ & Land trust & $\begin{array}{l}\text { Master- } \\
\text { space, all but one } \\
\text { building } \\
\text { Separate- } \\
\text { hot water, electricity }\end{array}$ & No & Chicago \\
\hline 30 & $15 / 1,000$ & Nonprofit & $\begin{array}{l}\text { Master- } \\
\text { space, } 900 \text { units } \\
\text { Separate- } \\
\text { Space, } 100 \text { units, } \\
\text { hot water, electricity }\end{array}$ & $\begin{array}{l}\text { Yes, } \\
850 \text { units }\end{array}$ & Chicago \\
\hline 31 & $7 / 1,277$ & $\begin{array}{l}\text { Corporate/ } \\
\text { Single proprietor }\end{array}$ & $\begin{array}{l}\text { Master- } \\
\text { space } \\
\text { Separate- } \\
\text { hot water, electricity }\end{array}$ & Yes & Denver \\
\hline 32 & $185 / 1,400$ & $\begin{array}{l}\text { Partnership/ } \\
\text { Single proprietor }\end{array}$ & $\begin{array}{l}\text { Master- } \\
\text { space, hot water } \\
\text { Separate- } \\
\text { electricity (all new } \\
\text { construction) }\end{array}$ & $\begin{array}{c}\text { Yes, } \\
1,050 \text { units }\end{array}$ & Chicago \\
\hline 33 & $14 / 3,200$ & Partnership & Mixed & Yes & Boston \\
\hline 34 & $80 / 3,600$ & Partnership & $\begin{array}{l}\text { Master- } \\
\text { space, hot water } \\
\text { Separate- } \\
\text { electricity }\end{array}$ & $\begin{array}{c}\text { Yes, } \\
50 \text { units }\end{array}$ & Denver \\
\hline 35 & $250 / 8,500$ & Partnership & Master & No & Boston \\
\hline
\end{tabular}


Table 2-2. METERING

\begin{tabular}{lccc}
\hline \multicolumn{1}{c}{ City } & Master $^{\mathrm{a}}$ & Separate $^{\mathrm{b}}$ & Mixed $^{\mathrm{c}}$ \\
\hline Boston $(\mathrm{N}=9)$ & 6 & 2 & 1 \\
Chicago $(\mathrm{N}=11)$ & 9 & 0 & 2 \\
Denver $(\mathrm{N}=6)$ & 2 & 3 & 1 \\
San Francisco $(\mathrm{N}=9)$ & 3 & 2 & 6 \\
\hline
\end{tabular}

${ }^{\text {a }}$ Master-metered buildings here are master-metered for space heat.

$b_{\text {In almost all cases, electricity for appliances and lighting was }}$ separately metered.

$\boldsymbol{c}_{\text {Mixed metering refers to at least one master-metered building and }}$ one separately metered building owned by the same landlord. Also in this category were buildings separately metered for heat and master-metered for hot water.

Table 2-3. NUMBER OF

LANDLORDS OWNING

STATE AND/OR

FEDERALLY SUB-

SIDIZED HOUSING

\begin{tabular}{lc}
\hline Boston $(N=9)$ & 3 \\
Chicago $(N=11)$ & 4 \\
Denver $(N=6)$ & 1 \\
San Francisco $(N=9)$ & 1 \\
\hline
\end{tabular}




\subsection{ANALYSIS}

Interviewers prepared a summary of background information on their particular city, including data about economic conditions, housing stock, fuel use, and the regulatory environment. Each interviewer's report also included a summary of the interviews, a brief description of the housing owners interviewed, what they perceived to be barriers to conservation investment, and their proposed solutions to energy conservation problems. Finally, the interviewers summarized solutions that best addressed local rental housing energy dilemmas. Interviewers submitted raw data from the interviews, city summaries, and interview summaries to the SERI project director.

Overall compilation and analysis of the interviews were conducted at SERI. From the interviews and the summaries, we compiled sets of barriers and solutions to energy conservation that landlords perceived to be most important. Given the owner profiles, we were also able to determine which barriers and solutions appeared most important to which types of landlords. Perceptions seemed to vary most according to how buildings were metered. In addition, landlords' perceptions varied according to the size of their holdings and their intended length of ownership; both of these variables interacted with the type of profit landlords were seeking. Landlords' perceptions of barriers and solutions are based on a nonstatistically selected sample of rental housing owners. However, given the careful selection of landlords interviewed and the high quality of information gathered from in-depth, unstructured interviews, the opinions listed here are likely to cover the entire range of concerns found among U.S. rental housing owners. 


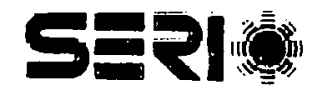




\section{SECTION 3.0}

\section{CONSERVATION MEASURES}

All the landlords interviewed, except one in Denver, had undertaken some energy conservation measures. The motive for energy conservation, in all cases, was financial. The propensity to install energy conservation measures tended to vary most according to how the buildings were metered. Landlords of master-metered buildings stood to save more money through energy conservation and were more willing to make larger investments than were owners of separately metered buildings; where impacts of energy costs had a less direct impact on operating expenses.

In any case, the complexity and costs of the energy conservation measures used varied tremendously. On the inexpensive and simple end of the scale, landlords lowered hot water temperatures and turned down thermostats. In more expensive, complex measures, many took renewed interest in boiler maintenance to improve fuel use efficiency. Still others reduced lamp wattage, changed lights from incandescent to fluorescent, insulated attics and walls, and installed storm windows. On the most expensive end of the spectrum, landlords with access to capital converted master meters to separate meters. Two landlords in Boston switched from fuel oil to natural gas. In San Francisco, four landlords installed active solar energy systems in their buildings.

\subsection{FINANCING}

For the most part, the landlords interviewed financed energy conservation measures out of their operating funds. Noting the extremely high cost of capital and the reticence of financial institutions to lend money for rental housing improvements, even landlords who had borrowed money in the past were extremely reluctant or unable to do so now.

For some relatively expensive improvements, however, some landlords did borrow money. In Boston, one landlord financed a new boiler through a contractor. Another converted a master-metered building to separate meters. He borrowed from limited partners and obtained some conventional financing. The mortgage holder, the Massachusetts Housing Finance Agency, increased the mortgage value. A'third landlord, who switched from oil to gas heating, also used a combination of loans: a Title I FHA Improvement Loan for investment property; a second mortgage; a rehabilitation loan from another bank, secured by the second mortgage; and a private loan from family members.

In Chicago, one landlord took out a loan from his credit union to finance storm windows. Two owners of subsidized properties financed a variety of energy conservation measures with a combination of funds from HUD, the llinois Housing Development Agency, GNMA, and conventional loan funds. A landlord in Denver said he would consider borrowing money to convert master meters to separate meters. Another landlord who had installed attic insulation in single-family rental houses at first financed the investment through the utility. The utility charged tenants on a monthly basis. This program ended; however, the landlord continued to charge the tenants and allowed them to take applicable state and federal income tax credits.

In San Francisco, the four landlords who had installed solar energy systems financed those systems with loans from Continental Savings and Loan. Continental offers 100\% 
financing, reduced-interest-rate loans for solar energy investments. The Savings and Loan started this program in conjunction with The Solar Center, a company that designs and installs solar energy systems.

\subsection{LANDLORDS' REASONS FOR ENERGY CONSERVATION INVESTMENTS}

The reasons landlords cited for taking energy conservation measures varied less than the measures themselves. Most often, landlords cited financial reasons for energy conservation. In cases where landlords could save energy but not money, they were highly unlikely to invest in energy conservation measures. Obviously, profit is the motive for owning rental housing. However, landlords sought to improve profits in two distinct ways. Landlords of master-metered buildings who intended to hold buildings for a relatively long time (longer than 7 years) and for whom annual cash flow was the primary type of profit, sought to reduce operating cxpenses. Fur lundlords of master-metered buildings, energy expenses have risen from approximately 5\% of gross rents in 1970 to from $25 \%$ to $30 \%$ in 1980 . These landlords saw energy conservation measures as opportunities to slow the rapid decline of cash-flow profit margins.

Landlords with shorter term ownership intentions sometimes saw energy conservation improvernents as adding to the capital value of their buidings. Only one landlord in Denver, who installed attic insulation in his separately metered single-family rental homes, expressed disappointment that energy conservation did not have a positive impact on resale value. However, the majority of landlords who were upgrading rental property, either for sale as rental property or for condominium conversion and sale, saw energy conservation measures as a wise investment that would improve the marketability of their properties as well as increase capital gains at the time of sale. (A rental building's capital value is often based on its projected annual income. Therefore, for mastermetered buildings, an improved cash flow resulting from energy conservation ought to improve the capital value of that building when the building is assessed on the basis of income. This reasoning does not apply to separately metered buildings, however.)

The second nuajur reason cited for conserving energy, by owners of both master- and separately metered buildings, was tenant appeasement. Landlords who owned relatively few units seemed the most concerned with keeping their tenants happy, mainly because the cost of turnover is proportionally higher for owners of few units. One owner in Denver claimed that tenant turnover cost $\$ 400$ per unit, and he preferred to invest that amount in attic insulation. In San Francisco, one owner invested in energy conservation for his buildings to maintain his positive image among his tenants.

In Boston, where fuel costs were highest, two landlords indicated that they had invested in energy conservation in separately metered buildings because without the conservation measures, their tenants would have been unable to pay for both utilities and rent. In one case, winter heating bills of $\$ 400$ per month were reduced by replacing a faulty boiler. In the other case, the landlord was making energy conservation investments in units where energy bills were over $\$ 1,000$ per unit per year. Although he had considered this an extreme situation, many of the units he owned were being "tightened up" at the time of the interview.

In San Francisco, where four landlords installed solar energy systems, reasons for doing so included financial and tenant-appeasement justifications. In addition, these landlords cited local financial incentives that made the investment very attractive. All four landlords worked through The Solar Center, a solar design and installation firm in San 
Francisco that offers technical advice, a thorough energy audit, financial counseling, low-cost financing, and installation-all in one package. The low-cost financing available through Continental Savings and Loan was an especially attractive selling point. In addition, the State of California offers attractive tax credits to landlords who invest in solar energy systems (see Appendix A). The four landlords who had installed solar energy systems also cited their personal interest in the technology as a reason for purchasing the systems.

\subsection{SUMMARY}

In sum, landlords invest more heavily in energy conservation if their buildings are master-metered because landlords in general are motivated by dollar savings rather than energy savings, and landlords of master-metered buildings can realize a more rapid reduction in the energy portion of their operating expenses through energy conservation. Some owners of separately metered buildings believe the resale value of their buildings will increase if they are energy efficient; but this belief is not universal and seems to hold only in cases where owners do not intend to keep buildings for long. The majority of landlords refused to borrow money for energy improvements, and some had trouble finding loans. All landlords, even those who had borrowed funds for energy conservation, cited extremely high interest rates as their reasons for drawing from operating funds instead of taking out loans.

Landlords in regions where energy costs are highest, such as Boston, appeared more concerned with energy conservation that those where energy costs still seem manageable, as in Denver. In Boston, energy costs are so high that even some landlords of separately metered buildings are engaging in energy conservation to the extent they can afford to because of many tenants' inability to afford both utilities and rent. The acceptance of solar energy systems was greatest in San Francisco where both the political climate and the financial incentives make solar energy attractive and economical as an energy conservation technique.

Surprisingly, rent control and rent stabilization, present in Boston and San Francisco, respectively, seemed to have little impact on landlords' propensity to invest in energy conservation. While landlords did not consider rent control to be beneficial to their operations in general, rent control did not appear to influence the decisions they had already made regarding energy conservation. 
SEPI* 


\section{SECTION 4.0 \\ LANDLORDS' PERCEPTIONS OF BARRIERS TO CONSERVATION INVESTMENTS}

The landlords we interviewed represented all levels of sophistication in their operations and all levels of experience and knowledge about energy. Consequently, responses about barriers to energy conservation that were of concern to landlords ranged from those who found virtually no barriers to those who cited problems in every barrier category listed in the interview checklist (see Appendix B). Landlords' concerns fell into five major categories:

- Information

- Finances

- Tenants and metering

- Technology

- Regulation.

Our purposive sample of landlords is not statistically representative of all U.S. rental housing owners. However, the in-depth interviews served to elucidate a wide range of concerns of different types of landlords.

\subsection{INFORMATION}

Nineteen landlords said they encountered information-related problems in their decisions to make energy conservation improvements. Some landlords complained of a lack of information, especially in professional journals or trade magazines. Others argued that there was too much information; and, in the words of one landlord, "it doesn't lead in one direction." Many landlords questioned the reliability of the information that was available. Eight landlords claimed that contractors, a customary information resource, were uneducated about energy conservation. Energy audits available locally either from private companies or from the utility were thought to be inadequate.

Several landlords found that the information they could obtain about energy conservation for residential buildings was not adequately tailored to landlords or to their particular building type. Information about tax credits and other tax benefits specifically geared toward rental housing owners also was perceived to be missing. Three landlords found their search for technical and financial information to be prohibitively time-consuming. They did not know whom to call for the information they sought. In three cases where the form of ownership was a limited partnership, the general partner interviewed had trouble convincing the other general partners that an investment in energy conservation would be wise, citing the lack of adequate, reliable cost information.

In general, landlords of master-metered buildings were more concerned with the apparent lack of reliable information, mainly because they were more interested in energy conservation to save money than were landlords of separately metered buildings. Also, landlords with large holdings seemed to have better access to information about energy conservation; they could assign a member of the maintenance crew to investigate 
energy-conserving options. Owners who held relatively fewer units tended to be selfeducated, or they relied on friends and associates for information.

\subsection{FIN ANCES}

Most landlords interviewed cited finance-related barriers to energy conservation. Seventeen landlords felt that the measures they contemplated were too expensive, especially because they had made decisions to finance energy conservation measures entirely out of cash flows. Twenty-one landlords complained that the cost of borrowing was too high to consider taking out loans. Insufficient tax benefits were a barrier for 22 landlords; there are no federal tax credits for landlords who invest in energy conservation measures. Two landlords were concerned that energy conservation improvements would increase their property tax liability.

A luck of access to capital or insufficient cash flow, or both, were barriers fnr 13 landlords. Access to capital was less of a problem to landlords in San Francisco who were acquainted with solar energy loans available from Continental Savings and Tinan. However, most owners complained of a lack of capital in general, not specifically related to rental housing energy improvements. Access to capital was more often cited as a problem for owners with relatively small holdings. Larger scale owners were of ten able to raise capital by liquidating some holdings, as in the case of condominium conversions in Boston. General partners also mentioned that borrowing from limited partners was possible. Small-scale owners felt that they had the option to take out a second mortgage, and one in Boston did; however, most were extremely reluctant to exercise this option.

Maintenance and other investments competed for what capital landlords did have available. Routine maintenance took precedence over energy conservation measures in almost all cases; however, maintenance responsibilities were especially competitive and burdensome for the nine landlords who owned subsidized housing. State and federal housing agencies typically have funds set aside for building operation and maintenance, with no special funds for energy-related expenses. One nonprofit corporate owner of subsidized housing said that repair costs resulting from theft and vandalism stripped her operating budget each year. Her feeling was that fluorescent light fixtures might son= serve electricity, but they would be bigger targets for vandals than incandescent light bulbs.

Five other landlords preferred to invest in cosmetic improvements such as landscaping for their buildings rather than in energy conservation measures. These landlords felt sure that cosmetic improvements would improve the marketability of their units and, therefore, improve both cash flow and capital gain at the time of resale. They were not so sure about the positive financial impacts of energy conservation.

For four landlords, investments in energy conservation measures competed with investments in more real property. One of these owners, a nonprofit developer, stressed that if his firm were to upgrade existing property, it would mean fewer housing units for lowand moderate-income families. One landlord mentioned his preference for owning a few high-quality (including energy-efficient) rental buildings, but this view was not predominant,

In summary, financial barriers were the ones most often cited by the landlords we interviewed. Although not statistically significant, the fervor with which landlords expressed 
their financial woes was impressive. All types of landlords except nonprofit owners lamented high interest rates and the lack of tax incentives. A surprising number felt that energy conservation measures were simply too expensive to finance out of operating incomes, and they were unwilling or unable to take out loans.

\subsection{TENANTS AND METERING}

Twelve landlords of master-metered buldings complained that tenants were wasteful. They saw no reason for making energy conservation improvements when "the tenants just leave the windows open during the winter." In addition, five landlords supposed that tenants would complain about any rent increases associated with energy conservation measures.

Ten landlords mentioned separate metering as a barrier. An analysis of the interviews suggests that, in fact, separate metering was the largest, most obvious barrier to energy conservation. Although landlords did not tend to mention their buildings' types of meters as barriers to energy conservation investments, it was clear that landlords of mastermetered buildings were taking more energy conservation actions than those owning separately metered buildings. In cases where a landlord owned both master- and separately metered buildings, energy conservation measures for the master-metered buildings took precedence. In cases where heat was separately metered and hot water was mastermetered, measures to reduce hot water consumption took precedence. There was iso little incentive to carry out energy conservation measures in separately metered buildings that one owner in Denver said he had made not one energy-related improvement in any of his 15 buildings. "Nothing would be cost effective in separately metered buildings," he claimed. Only in cases where landlords of separately metered units had a special interest in keeping their tenants happy did we find investment in energy conservation. The policy implications from these findings are that conversion from master meters to separate meters removes existing market incentives.

\subsection{TECHNOLOGY}

Problems with installing energy conservation devices, including solar energy systems, were not pervasive. However, 13 landlords mentioned that either they would have trouble insulating brick walls, or they couldn't find storm windows to fit, or they had no solar access. Seven landlords questioned the reliability of certain technologies, especially active solar energy systems, and doubted they would actually achieve the payback periods quoted either by contractors or in the literature.

Four landlords, mainly those owning subsidized housing, were fearful that energy conservation measures would be subject to vandalism. A number of landlords said vandalism would not be a problem because measures did not have to be accessible to anyone but maintenance crews. However, in Boston, one landlord was hesitant to install interior storm windows. One landlord of subsidized housing in San Francisco wanted to add southfacing glazing for heat gain, but she felt the glazing would have to be plastic to protect against breakage. For two landlords in Boston, who had converted some of their units from fuel oil to natural gas, continued supplies of natural gas were a concern. One landlord hoped to convert from fuel oil to natural gas in one more building but wanted first to determine the availability of natural gas. 
The aesthetics of energy conservation measures were a concern to five landlords. In Boston, one owner was unwilling to install storm windows on a historic building. The other four landlords were concerned about the aesthetics of solar energy systems. However, concerns were dispelled for two of these owners when they discovered that the collectors, once installed, would not be visible from the street.

\subsection{REGULATIONS}

Of the regulatory barriers to energy conservation in rental housing, rent control regulations were mentioned most of ten (by a total of nine landlords in Boston and San Francisco). According to these landlords, rent control made it difficult to raise rents to a sufficient level to cover rising energy costs. In both Boston and San Francisco, rent control. or rent stabilization regulations allow arı "energy pass-through"; landlords may charge tenants for utilities separately and add that amount to the rent. Our analysis suggested that especially in Boston, the landlords' objection resulted primarily from the time lag between the time when they were charged for utilities and the time when they could actually recoup that expense through the rent. Having to comply with yet another regulation was also onerous to landlords. Analysis also showed that the relative ease involved with the "energy pass-through" as opposed to the difficulties associated with following regulations for amortizing energy conservation investments made it easier to charge tenants for rising energy bills than for energy-related improvements.

For eight landlords, building codes proved to be a barrier. HUD codes and fire codes conflicted with building codes. In other cases, in Boston and Chicago, building codes appeared out-dated. One landlord in Boston mistrusted building inspectors to such an extent that he tape-recorded all sessions with them. Seven of nine subsidized housing owners complained that federal regulations associated with their subsidies were a barrier. Five said the problem was the lack of a special expense fund for energy improvements; i.e., any energy conservation measures had to be financed out of the general (and tight!) operating and maintenance budget. Two landlords felt that federal regulations covering their housing did not encourage energy conservation. One owner expressed concern about the insurability of energy conservation measures, especially solar energy systems.

In general, according to the landlords interviewed, rent-control regulations stood out as posing the greatest barrier to energy conservation.* Landlords also cited building code conflicts with other codes or with installation of energy-conserving devices. Owners of subsidized housing felt that federal regulations did little to promote energy conservation.

*However, it is important to note that rent-control regulations were not cited as interfering with energy conservation measures already taken by landlords in Boston or San Francisco, where rent control or rent stabilization is in effect (see Sec. 3.0). 


\section{SECTION 5.0}

\section{LANDLORDS' PERCEPTIONS OF SOLUTIONS TO ENERGY CONSER VATION PROBLEMS}

For the most part, the solutions landlords preferred for solving their energy conservation problems mirrored what they had perceived as barriers to investment. In addition, many landlords took a broader view of their energy conservation problems and devised imaginative ways of overcoming sets of barriers.

The amount of time they devoted to researching and solving their own energy problems varied greatly among the landlords interviewed. Answers ranged from that of the landlord of separately metered townhouses in Denver, who said, "I haven't thought much about energy" to that of the owner-occupant of a master-metered, four-unit building in San Francisco, who stated, "The only way to get energy conservation and solar energy use on a pervasive scale is to change our entire economic and political system."

Solutions preferred by the landlords interviewed fell into five major categories:

- Information

- Finances

- Tenants and metering

- Regulation

- Packaging.

In addition to an open-ended question about solutions the landlords preferred, we asked specifically about two solutions in which we had special research interest: (1) packaging audits, technical assistance, financial assistance, and installation; and (2) regulations requiring compliance with energy efficiency standards. Landlords' opinions concerning these two solutions are discussed in detail in Secs. 5.4 and 5.5.

The solutions described here are based entirely on the interviewed landlords' points of view; therefore, they are not necessarily the most equitable ways to encourage energy conservation in rental housing. Predictably, most landlords offered solutions from their own perspectives; they were not based on the needs of tenants. Also, it is not clear how most of these solutions would encourage energy conservation in separately metered rental housing. We discuss these issues in more detail in Sec. 6.0.

\subsection{INFORMATION}

Obtaining reliable information was a popular solution among landlords interviewed; twenty-six landlords saw the need for information they could trust. Six landiords wanted to see product evaluations to help them select technologies for energy conservation. Three landlords said they would feel more certain about energy conservation investments if the products had warranties or guarantees.

Seven landlords wanted better quality information from contractors. Of these, six found contractor education to be appropriate, and one wanted contractors to allow the use of cuniseivation measures on a trial basis. 


\subsection{FIN ANCES}

As was the case with the finance-related barriers mentioned, finance-related incentives were the most popular among the landlords. A large majority of those interviewed (27) wanted some type of additional tax benefits. The tax benefits mentioned included accelerated depreciation for energy conservation measures, special federal and state income tax credits, and property-tax exemptions for energy-related added value. One owneroccupant in Boston who was self-employed did not have a sufficient income to take advantage of any tax credits; he wanted to see refundable tax credits in place.

The second most popular solution for landlords was low-cost loan financing. Although the majority of landlords interviewed were averse to using loan money for energy conservation, the major reason was the extremely high cost of capital. Reduced interest rates for energy conservation measures were apparently very attractive to landlords. In San Francisco, the four landlords who had installed solar energy systems all obtained reduced rate financing from Continental Savings and Luan. All four stated that low-cost financing was important to their investment decisions. Grants, especially for tenants, were a preferred solution for seven landlords, most of whom owned subsidized housing for low or moderate-income households.

Eight landlords expressed an interest in increased utility involvement in energy conservation financing. These landlords cited utility rebates or loans as a way to lessen the landlords' cost of energy conservation. And seven landlords expressed an interest in leasing energy conservation equipment, including solar energy systems. Although several landlords discounted leasing because they would lose the opportunity to deduct the investment from income tax, these seven argued that leasing would remove much of the risk they associated with uncertain performance and uncertain actual energy savings. Although 17 landlords felt that energy conservation measures were too expensive, only three suggested reducing the cost of measures through government investment.

One landlord's specific solution to the apparently high cost of energy conservation was to guarantee a short (two-year) amortization of conservation investments through rent increases. Another landlord preferred financial incentives for tenants who paid their own utility bills. One landlord in Chicago who was rehabilitating rental housing suggested additional financial assistance for government-sponsored housing rehabilitation programs so that energy conservation measures could be included.

\subsection{TENANTS AND METERING}

Tenant-related solutions were more popular with landlords who owned relatively fewer units and were concerned with good landlord/tenant relations to minimize the cost of tenant turnover. Nine landlords said that, given the materials, they would try to educate their tenants about energy use. One of these landlords was already prcparing a brochure for tenants listing what he had done about energy conservation and what the tenants could do to help. Six landlords were willing to negotiate some means of sharing the costs of energy conservation with tenants.

Eight landlords of master-metered buildings believed conversion to separate meters to be a solution to their energy conservation problems. According to one owner of both master-metered and separately metered units in Chicago, the only solution was to "make the user, whether the owner or the renter, responsible for energy costs!" However, from data analysis, it is clear that landlords who convert from master meters to separate 
meters lose further incentives to invest in energy conservation measures. A number of landlords, in fact, reacted negatively to the idea of tenant-related solutions. For the most part, they owned a great deal of property, and felt that working with tenants is too costly in terms of both time and money.

\subsection{REGULATION}

In general, the regulation-related solutions preferred by landlords were for changes in existing regulations that they saw as barriers to conservation investments. We asked a specific, open-ended question about landlords' reactions to mandatory energy-efficiency standards. Their reaction was unequivocally negative. But when interviewers probed, a few landlords confessed that mandatory standards would be the only way to achieve energy efficiency in separately metered rental housing. One landlord expressed dismay at the lack of responsibility of many of his colleagues toward tenants, and he felt mandation to be the only way to overcome this problem in the case of some individuals. However, even those landlords who believed mandatory energy-efficiency standards to have merit were fearful that the cost of complying with standards would ultimately result in higher rents and be detrimental to tenants. Only one landlord favored energy performance standards, for federally subsidized housing. He believed that increased subsidies to cover the cost involved would be essential.

Five landlords favored changes in building codes as a way to overcome the barriers discussed in Sec. 4.5 of this report. And four landlords (out of 18 interviewed in cities with rent control) favored changes in rent control regulations; two wanted simpler energy regulations and the other two favored the elimination of rent control.

Considering energy problems from a broader perspective, two landlords favored a change in utility rate structure. Both wanted to see a base rate charged for reasonable use and a much higher rate for those who used more than the reasonable base; "as long as they don't lock me into the amount I used during a mild winter," cautioned a landlord in Chicago. And two landlords, neither of whom resides in San Francisco, wanted to see local ordinances protecting solar access enacted. Three landlords viewed their energy problems as part of much larger national and even global problems; therefore, they proposed various large-scale measures for solving them.

\subsection{PACKAGING}

Fifteen landlords reacted positively to the notion of "packaging" information, installation, and financing. Four landlords in San Francisco had contracted with The Solar Center, a company that provides this type of complete service, and all four were reasonably happy with the outcome. Landlords favoring packaging cited time savings, reliability, and a single source for all energy-related services as advantages of a packaged building energy management scheme.

Some landlords, however, were skeptical. One landlord in Denver claimed that "the market isn't ready for that kind of company." He knew of two such companies that had folded because of a lack of customers. Other landlords' skepticism arose from a general mistrust of information from contractors who are also selling a product. Still others felt they already had the knowledge required to piece together the components of an energy conservation plan for their buildings. One landlord in Denver, who owned a few units, maintained that packaged energy services would be too expensive for the small-scale 
owner. On the other hand, several large-scale rental housing owners had experienced maintenance staffs who, once appropriately educated, could perform the services offered by an energy management company.

\subsection{SUMMARY}

According to the landlords interviewed, the most popular solutions to their energy problems were financial ones. All types of landlords, regardless of how their buildings were metered, the scale of the operations, their intended length of ownership, their form of ownership, or their preferred type of profit, favored improved tax benefits. Almost as many approved of low-cost loans for energy conservation measures. Those landlords who no longer borrow money for building improvements said they would take out loans if the cost of capital were lower and capital access were assured. Information-related solutions were also popular among landlords. Most important, they felt, was that information be reliable.

Tenant-related solutions were common for landlords who owned relatively few units. These landlords felt that establishing and maintaining good relations with their tenants reduced the cost of maintenance and turnover. Many landlords of master-metered buildings preferred to shift the rising costs of energy. to tenants directly through meter conversion. Some realized that meter conversion would remove their incentive to invest in energy conservation, but most simply wanted relief from the burden of rising utility bills. Equitable cost-sharing between landlords and tenants was rarely a consideration. Regulatory incentives and packaging were also favored by several landlords.

Cost savings always took precedence over energy savings. Therefore, in separately metered buildings where a landlord's investment in energy conservation would save energy (and money for the tenant) but would not result in substantial dollar savings for the landlord, the landlord was unlikely to make that investment. 


\section{SECTION 6.0}

\section{FINDINGS AND CONCLUSIONS}

From 35 unstructured, in-depth interviews with diverse types of landlords in four cities, we were able to identify substantive concerns about their energy conservation problems. Although the sample is not statistically significant, it was purposely chosen to represent a wide variety of viewpoints in the rental housing section. The sample was sufficiently diverse to achieve that end.

\subsection{FINDINGS}

All landlords but one had carried out some energy conservation measures, from lowering thermostats to installing solar energy systems. It was clear, however, that owners of master-metered buildings had done more to conserve energy than had owners of separately metered buildings, in part because dollar savings were more important to the landlords interviewed than were energy savings. In cases where a landlord owned both master- and separately metered buildings, the landlord had taken steps to conserve energy in the master-metered buildings first. In cases where space heating was separately metered and hot water was master-metered, landlords investigated measures to conserve hot water first. Thus, how buildings were metered was the single most important indicator of landlords' propensity to invest in energy conservation measures.

The size of a landlord's holdings tended to indicate what types of barriers were perceived to be most important and what types of solutions to problems were preferred. Landlords with relatively large holdings tended to have more access to energy information. Also, they tended to have better access to capital through liquidation of some holdings, larger cash flows, and, where applicable, loan funds from limited partners. Concern about good relations with tenants appeared less important to large-scale owners because the cost of tenant turnover was proportionally less for them than for small-scale owners.

Intended length of ownership also indicated which barriers and solutions were likely to be cited. Speculative landlords tended to upgrade property for sale. Cosmetic improvements tended to be most important, and in some cases, energy conservation improvements were considered cosmetic and of value in enhancing sales price. Long-term owners were most concerned with stable cash flows. While many perceived the potential contribution that energy conservation could make toward this end, their current cash flows were not sufficient to finance many energy conservation measures. For these landlords, low-cost loans apparently would be an important solution. The problems and solutions outlined by the landlords followed similar sets of topics. Barriers to investment in conservation were cited in five major areas: information, finances, tenants and metering, technology, and regulations. Proposed solutions also fell into five categories: information, finances, tenants and metering, regulations, and packaging. In general, landlords' doubts about the technologies available for energy conservation and about their technical reliability and applicability were barriers. Few landlords, however, offered solutions to these problems.

Landlords who viewed their energy problems as a whole approved of the idea of one firm selling all energy conservation services for rental housing, although a lack of packaging information was not often cited as a barrier. Most interest in such packaging came from landlords of master-metered buildings whose holdings were small enough that they did not employ a regular maintenance crew. 


\subsection{CONCLUSIONS}

This report presents landlords' views of their own, fundamentally profit-driven concerns. The issues of energy use and energy conservation in rental housing are complex (Levine and Raab 1981). Analysis of what motivates landlords to make energy conservation improvements to their buildings suggests that forces disruptive to the rental housing market as a whole-including declining profitability, escalating operating expenses, and the inability to cover expenses plus profits with current rents-are stronger than the perception that energy conservation can stabilize that market. This holds true especially for owners of separately metered rental units [nearly 70\% (Levine and Raab 1981)] who have virtually no reason to conserve energy in their rental buildings.

Landlords' perceptions alone cannot shape policy or be used to design programs. The results of our interviews require analysis in the context of the entire rental housing market-a sector plagued by shortages, disinvestment, a high proportion of low-lncome households, and a traditionally antagonistic relationship between landlords and tenants. Real solutions to the energy conservation problems associated with rental housing are possible at the state and local levels (Raab and Levine 1081), though few progrums exist currently, and most that are in place are relatively new. Real solutions must take into account the rental housing emergency in the United States (GAO 1979). Finally, real solutions should distribute the costs and benefits of energy conservation equitably among tenants and landlords.

The solutions that landlords preferred most often-tax benefits, low-cost financing, and information-are all available in San Francisco. Although there was some indication of heavier investments in energy conservation measures for master-metered buildings in San Francisco, even with the presence of preferred incentives there was no indication of heavier investments in separately metered buildings. After analyzing landlord responses in the context of actual investment, we inferred that if state and local government officials sense a need for energy conservation in rental housing in the near future, mandatory standards for energy efficiency may be the only answer. However, given landlords' generally negative responses to mandation, standards may need to be accompanied by financial assistance and reliable information. 


\section{SECTION 7.0 REFERENCES}

Ashworth, John; et al. 1980. Building Markets for Solar Energy and Energy Conservation. Working paper. Golden, CO: Solar Energy Research Institute.

Friedman, Stephen. 1981. "Multi-Family Energy Conservation: Owners' Perspectives." Multi-Family Energy Conservation: A Reader. Edited by Steven Kaye. Prepared for the Workshop on Multi-Family Energy Conservation, Boston, Mass., May 11-12, 1981.

General Accounting Office. 1979. Rental Housing: A National Problem that Needs Immediate Attention. Prepared for the U.S. Congress. CED-80-11. Washington, DC.

Levine, Alice; Raab, Jonathan. 1981. Solar Energy, Conservation, and Rental Housing. SERI/RR-744-901. Golden, CO: Solar Energy Research Institute.

Raab, Jonathan; Levine, Alice. 1981. "State and Local Programs to Encourage MultiFamily Energy Conservation." Multi-Family Energy Conservation: A Reader. Edited by Steven Kaye. Prepared for the Workshop on Multi-Family Energy Conservation, Boston, Mass., May 11-12, 1981. 


\section{SEPY}




\section{APPENDIX A}

\section{OVER VIEW OF CFTIES}

\section{BOSTON}

Boston's population in 1975 was 638,000 . Of the city's 232,228 housing units, $74 \%$ were rentals in 1970. Most of the city's housing stock is in woodframed triple deckers where at least two of the three units are rented. Boston's supply of housing tightened considerably during the late $1970 \mathrm{~s}$. Estimates of the overall vacancy rate range from a low of $1 \%$ to an optimistic 5\%. Also, the rate of condominium formation is accelerating and projected to generate more than 12,000 units by 1980. In addition, the expected erosion of 6,800 older private apartments reflects some conversion to condominiums, some renovation through Section 8 assistance, and some demolition.

Fuel oil is the dominant heating fuel in Boston. Fifty-nine percent of the residential units are heated by oil, $34 \%$ by natural gas, and $7 \%$ by electricity. Three-quarters of Boston's housing is more than 40 years old; the majority of units are master-metered. In 1980 , the average residential heating cost for units using fuel oil was $\$ 1,200 ; \$ 850$ for units using natural gas. This reflects both Boston's 5,634 heating degree days and its reliance on imported fuel.

Rent control was instituted in the late 1960s. A weakened version of rent control known as "vacancy decontrol" was enacted in 1975. Under this system, controls on units that are vacated are automatically lifted to permit landlords to increase rents to the level that the market will bear. Vacancy decontrol currently affects 50,000 housing units occupied by 95,000 people, or $15 \%$ of the city's population. A provision of the control grants landlords adjustments of rents based on rising operating costs and capital improvements.

Although the Commonwealth of Massachusetts has a state income tax credit for costs incurred in the installation of renewable energy systems, owners of rental property are ineligible unless the property is their principal residence. Also, local financial institutions claim to be offering extended-term and reduced-rate loans for energy improvements, but the extensions and discounts are not having a significant market impact.

\section{CHICAGO}

Chicago's population in 1970 was $2,986,400$. Of the $1,207,145$ housing units, approximately two-thirds are more than 40 years old and nearly $80 \%$ were in rentals in 1970 . Of the rental housing, slightly more than $4 \%$ are single-family structures, $44 \%$ are in $2-$ to 4-unit buildings; $35 \%$ are in 5- to 49-unit buildings, and $17 \%$ are in structures of 50 or more units. Although the city's population has declined $11.4 \%$ in the past decade, the number of households has declined only $3.9 \%$, reflecting the increase in single-parent families and single people living alone. Thus, the decrease in population has not led to a comparable decrease in the demand for housing. The vacancy rate in the rental housing market varies greatly by neighborhood. Along the north lakefront, the vacancy rate is effectively zero, whereas in some of the inner-city communities, the vacancy rate ranges between $5 \%$ and $15 \%$. In more stable communities, the rate varies between $5 \%$ and $10 \%$. Housing abandonment is a major problem; an estimated $10 \%$ of the housing stock has been abandoned in the past decade. 
Since the early 1970s, use of coal for residential heating within the city has been banned. It can be assumed that almost $80 \%$ of the conversions from coal and coke were to natural gas. In addition, there have been many conversions from fuel oil to natural gas. A current conservative estimate is that $85 \%$ of Chicago's housing units heat with gas and the remaining $15 \%$ with electricity. Since $80 \%$ of the housing units are heated with steam hot water, or central warm air, it can be assumed that they are mastermetered. Also, because master metering for electricity in residential buildings has been banned since 1954, one can assume that approximately $20 \%$ of Chicago's housing stock is separately metered.

Chicago has a fairly windy and harsh climate with 6,155 heating degree days. Consequently, energy costs are high relative to other U.S. cities where natural gas is the predominant fuel used. The cost of heating a building in Chicago with natural gas rose $18 \%$ between 1979 and 1980 .

The Community Investment Corporation (CIC) manages a private financing pool of 32 participating banks and savings and loan associations. Recently, the CIC launched a program for existing, owner-occupied 2- to 6-unit structures to encourage $1 / 9$ of each home improvem ent loan to be targeted for energy conservation measures. The lllinois Housing Development Authority has come under criticism recently for not issuing revenue bonds for rehabilitation projects and may do so in the future. Thus, it could become a major source of affordable home improvement capital for multifamily buildings. The South Shore Bank is the only commercial bank in Chicago with a program for multifamily home improvement financing. The South Shore Bank has pioneered in offering package home improvement financing, including energy improvement financing, for large multifamily property owners. Most of the current publicly financed incentive programs to invest in energy alternatives will either be disappearing in light of federal budget cuts or are difficult to apply to the problems of energy conservation investments in multifamily structures.

\section{DENVER}

Denver's population in 1977 was 520,000 . Of the city's 225,000 housing units, $51 \%$ were rental units in 1980. Nearly $16 \%$ of the rental housing is in single-family units, $19 \%$ is in 2 - to 4-unit structures, and $61 \%$ is in buildings of 5 or more units. Denver's vacancy rate in 1981 ranged between $1.5 \%$ and $8.4 \%$ for units renting for $\$ 301-\$ 350$ and $\$ 151-\$ 200$, respectively. Conversion of apartments to condominiums accelerated in 1978 and 1979 , but has since declined somewhat. The prime barrier to greater conversion has been the high cost of capital needed for the conversion process.

Utility-provided natural gas is the dominant heating fuel in the Denver metropolitan area. In $1976,94 \%$ of the housing units used utility gas as the heating fuel, and only $4 \%$ used electricity. In rental property, 52\% of the units use warm-nir furnnens; $40 \%$ use steam or hot water heating systems; $3 \%$ use electricity; $3 \%$ use room heaters; and only $2 \%$ use floor, wall, or pipeless heaters. It has been estimated that most properties with less than five units use separately metered gas while $60 \%$ to $80 \%$ of the properties with more than five units use master-metered gas.

Denver has a relatively moderate and very sunny climate with 5,524 degree days. Given the predominance of natural gas as the heating fuel and its low relative cost until the late 1970s, energy costs have remained relatively low. The average annual residential energy bill for gas and electricity in 1980 was $\$ 690$. 
Denver does not have rent control regulations. Owners can pass through escalating fuel costs to tenants either through rent increases or through tenant-paid utilities. However, to remain competitive in the marketplace, many owners of master-metered buildings have not passed on all escalating fuel costs.

Owners of rental property in Denver are not eligible for the state solar and conservation tax credits. Local financial institutions do not offer low-interest home-improvement loans for energy conservation measures to nonoccupant owners of rental property. In addition, current high costs of borrowing deter owners of rental property from considering property improvements.

\section{SAN FRANCISCO}

San Francisco has a population of 679,000 . Two-thirds of San Francisco's 320,000 residential units are rentals. Approximately $8 \%$ of the rental housing is in single-family structures; $32 \%$ is in 2- to 4 -unit structures; $45 \%$ is in 5 - to 49 -unit structures, and $15 \%$ is in structures with over 50 units. The housing market in San Francisco is extremely tight. The vacancy rate is between $0.5 \%$ and $2 \%$; evictions are on the rise; average rent is $\$ 470 / \mathrm{month}$, and rampant condominium conversion has been curbed by the San Francisco Board of Supervisors by limiting conversions to 1,000 units per year.

Only $13 \%$ of all the natural gas and $6 \%$ of all the electricity consumed in the residential sector is master-metered. Most housing in San Francisco is separately metered. Natural gas provides most of the space and water heating for San Francisco's residential sector. Electricity provides less than $12 \%$ of the space heating and less than $5 \%$ of the water heating; fuel oil is not used. In 1975, approximately $35 \%$ of the rental housing used steam or hot water systems; $24 \%$ used warm air furnaces; $16 \%$ used room heaters; $16 \%$ used floor, wall, or pipeless heaters; and $6 \%$ had built-in electric heating systems.

San Francisco has a fairly mild climate with only 3,015 degree days. As a result, energy costs are low relative to other cities in the United States. In 1980, the average annual residential energy bill for gas and electricity was $\$ 400$.

The rent stabilization ordinance in San Francisco allows owners of master-metered buildings to assess an energy surcharge. The surcharge, which is separate from the rent and can be reassessed every six months, allows owners to pass through all escalating fuel costs. At the same time, owners are allowed to pass through the cost of conservation and solar energy investments to their tenants over a 5- or 10-year period, depending on the particular investment.

Owners of rental property and tenants in San Francisco are eligible for the State of California's $55 \%$ solar tux credit and $40 \%$ conservation credit. For the solar credit, owners or tenants are allowed to take $55 \%$ of the cost of any system under $\$ 12,000$ for a maximum credit of $\$ 3,000$. For systems costing more than $\$ 12,000$, owners or tenants can receive a credit for $25 \%$ of the system's cost. The conservation credit entitles the landlord or tenant to a $40 \%$ nonrefundable tax credit to a maximum credit of $\$ 1,500$. The conservation credit is also available to tenants, but they must hold a 3 -year lease in order to qualify.

Continental Savings and Loan of San Francisco has set up a Safe Energy Fund. From this fund, the institution lends money to rental housing owners for solar energy investrnents at about $2 \%$ below its normal home-improvement loan rate. The money in the fund is 
raised by the sale of "Solar T-Bills" and "Solar T-Notes." The relatively low-interest, 20year loan term and $100 \%$ financing have already proven sufficiently attractive to many rental housing owners who have used the loans to finance conservation and solar energy investments. 


\section{APPENDIX B}

\section{INTER VIEW CHECKLISTS}

\section{OWNER PROFILE}

1. Name

2. Building Information
A. Number of buildings
B. Location (city/state)
C. Form of ownership
D. Type of management
E. Subsidized?
F. Metering type
G. Age of buildings

3. Owner Information
A. Years in real estate ownership
B. Years usually holds on to a building
C. \% of investment portfolio in rental housing
D. Remainder of portfolio-how invested
E. Type of profit sought (annual income, tax benefits, capital gain)
F. Return calculated? How?
G. What basis for rent increase
H. \% annual operating income spent on maintenance
I. Impacts of rising energy costs on operations
J. Owner's self-assessment as representative 


\section{APPENDIX B (Continued)}

\section{TECHNOLOGIES}

\section{Space Heating}

Boiler/furnace efficiency improvements

Controls improvements

High temperature limit thermostats

Thermostatic radiator valves

Clock thermostats

Energy monitoring and control systems

Insulate distribution piping and ductwork

Reduce excess outside air*

Building envelope thermal performance improvements

Caulking and weatherstripping

Attic/roof insulation

Storm windows

Increase winter solar gain

Equipment conversion from one conventional fuel to another

Active solar

Domestic Water Heating

Insulate DHW tank and distribution piping

Reduce DHW temperature*

Timer on DHW recirculation pump*

Faucet flow reducers

Snlar pnergy*

Lighting

Reduction of lamp wattage

Installation of timers on exterior lighting

Convert incandescent to fluorescent lighting

Space Cooling

Install shading devices to avoid solar gain in summer

Use light color when repainting facades and replacing roofs

Equipment efficiency improvements

Controls improvements

Dther

Convert to individual metering for electricity and decentralized heating, cooling, and DHW systems

Energy cost indicator (feedback meter) for individually metered units

Use meter for owner

Building audit

*Code compliance requirements applicable in some locations. 
APPENDIX B (Continued)

\section{BARRIERS}

Information Barriers (cost and access)

Lack of familiarity with technologies

Costs too high

Contractors unable to assist

Audits unavailable or unreliable or too expensive

Doesn't know where to shop for energy items

Reliable sources unavailable or against such investments

Previous bad experiences with energy-related investments

Tenant-Related Barriers

Separate metering exists

Tenants' wasteful habits

Tenant resistance to $\mathrm{C} / \mathrm{S}$ measures

Bad tenant/owner relations

Theft/vandalism of devices

Financial Barriers

Too expensive

Access to capital

Cost of capital

Unable to package an application

Source of capital unattractive

\section{Tax Considerations}

Credits too low or unavailable

Property tax would increase

General tax structure favors energy wastefulness

Technical Barriers

Difficulty of retrofit

Doubtful reliability of technologies

Solar access does not exist or is unprotected

Space requirements too great

Contractors, suppliers, installers don't know how

Appropriate technology doesn't exist

Monitoring is difficult

$\underline{\text { Regulatory Barriers }}$

Rent control

Building codes (rehab, codes, no solar access protection)

Federal and state regulations for subsidized housing

Lack of standards for conservation and/or solar 
APPENDIX B (Concluded)

\section{Utility Regulations}

Rate structures

Cost of conventional fuel artificially low

Availability of other fuels

Local Market Conditions (refer to length of tenure in profile)

Tight market

Declining or upgrading neighborhoods

\section{Competing Investments}

Other maintenance responsibilities

Other investments in general

Lack of Packaging

Time involved

Lack of standards

Lack of convenience

\section{PROPOSED SOLUTIONS}

Inf ormation: audits, reliability

Tenant solutions: cooperation, convert metering

Financing: terms, availability, leasing

Tax benefits; tax code changes

Technology: warranties/guarantees, contractor education, co-operative buying

Rcgulatory: required standards, ient cuntrol ehanges, solar access guarantees

Losal market conditions

Education: How energy improvements can be part of regular maintenance

Packaging: availability of information and services in one place

Mixing solutions: financing/leasing/mediation/regulation 